環境感染誌 Vol. 36 no. 3, 2021

〈proceedings〉

\title{
感染制御活動において薬剤師が力を発揮するためには？
}

小野寺直人

\section{What Should Pharmacists Do to Contribute Their Expertise to Infection Control Activities?}

\author{
Naoto ONODERA
}

Department of Infection Control and Prevention, Iwate Medical University Hospital

(2020 年 10 月 15 日受付 $\cdot 2020$ 年 12 月 24 日受理)

\begin{abstract}
要 旨
感染制御とは病院内すべての患者や職員に対する感染症の発生予防と拡大防止を目的とし，医療 の安全と質の向上に大きく寄与する。職種横断的な関わりが必要な感染制御活動において, 薬剤師 の果たすべき役割は少なくない。岩手医科大学附属病院では, 2004 年 4 月に専従薬剤師が感染症 対策室に配属されて以降,「感染経路別ゾーニングシステム」や「包括的抗菌薬処方管理策」の導 入,「手指衛生向上に向けた取り組み」など，薬剤師も積極的に関わっている。感染制御専門薬剂 師の理念は，抗菌薬の適正使用のみならず消毒薬や医薬品に関連する感染制御活動など，総合的な 観点から関与するとしている，感染制御活動において薬剤師が力を発揮するためには，感染制御部 門である感染制御チーム（ICT）扔よび抗菌薬適正使用支援チーム（AST）での相互的な立ち位置 を意識し，目に見える成果を上げることが望まれる，そこには薬剤師ならではの“情報収集・分析” の偏重から“企画・立案”にチャレンジし，自ら責任を負う覚悟も必要である。感染制御活動を俯 瞰し, 薬学の知識を基本とした科学的エビデンスにこだわった感染対策の立案, 効率的な運用と的 確な評価を行って，成果に導くことがその実現に向けた近道になると考える.
\end{abstract}

Key words：感染制御，ICT，AST，感染制御専門薬殽師

\section{はじめに}

近年の医療の高度化や高齢化社会にともない, 侵襲的 な手術や治療, 免疫低下宿主の増加などを要因とする医 療関連感染が大きな社会問題となっている。このような 状況下，感染症に対する的確な診断と治療のみならず, 感染症の発生予防と拡大防止を目的とする感染制御の重 要性が高まっている ${ }^{1)}$. 感染制御は医療の安全と質の向 上に寄与し, 感染制御活動を行う組織は病院運営にも貢 献する病院管理部門でもある. そのため, 常に結果が求 められ, 病院管理者に理解を得るための根拠の提示が不 可欠である，また，その活動は多岐にわたっており，医 師や看護師だけではなく, 薬剤師や臨床検査技師, 事務 部門等が参加する職種横断的な関わりが必須である ${ }^{2,3)}$. 薬剂師も感染制御活動で大きく貢献する必要があるが, 活動時間が限られる状況でどのような立ち位置で対応す

岩手医科大学附属病院感染制御部
べきかについて悩む点が多い4)，本稿では薬剤師に焦点 を当てて，「感染制御活動において薬剤師が力を発揮す るためには」と題して, 岩手医科大学附属病院（当院） 感染制御部の薬剤師の具体的な活動を紹介するとともに, 感染制御活動における薬剤師の使命とその在り方につい て述べる.

\section{当施設の概要}

当院は一般病床 932 床, 精神科病床 68 床を有する特 定機能病院・臨床研修指定病院・災害拠点病院である. 標榜診療科は 44 科で, 2019 年度の平均外来患者数は 1,221 人/日，平均入院患者数が 792 人/日，年間手術件 数が 9,101 件/年であった. 感染制御部（当時は感染症 対策室）は 2003 年 4 月に設置された病院長直轄の組織 で, 現在では感染制御部長の専任医師 (Infection Control Doctor：ICD）が 1 名, 感染制御部副部長の専任薬剤師 (Board Certified Infection Control Pharmacy Special- 


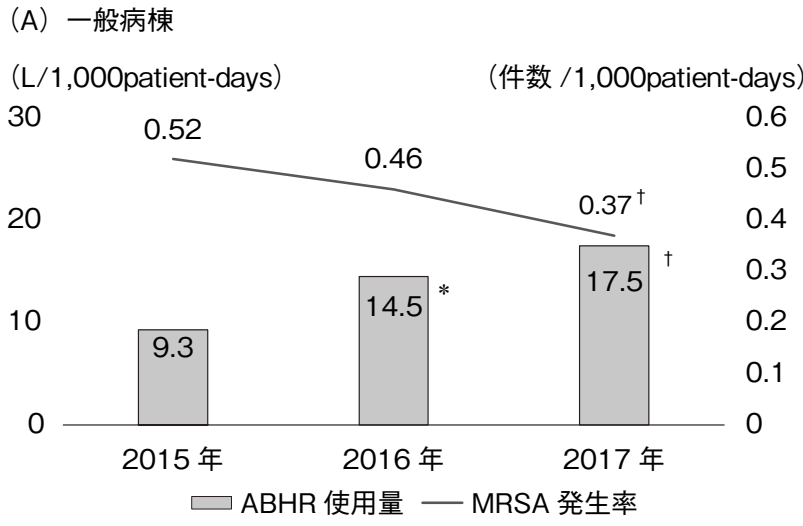

MRSA : methicillin - resistant Staphylococcus aureus ABHR : alcohol-based hand rub * $P<0.05$ (2015 年 vs. 2016 年) $\quad{ }^{\dagger} \mathrm{P}<0.05$ (2015 年 vs. 2017 年)
（B）クリティカル部門

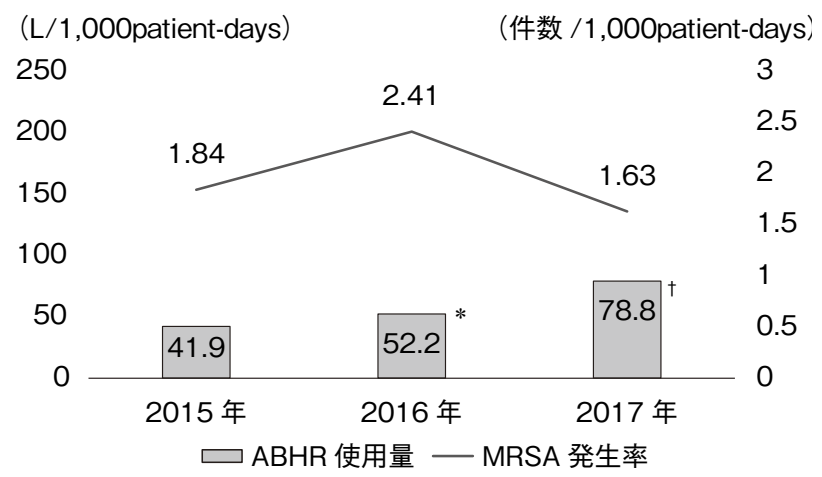

図 1 ABHR 使用量と MRSA 発生率

ist : ICPS, Infectious Disease Chemotherapy Pharmacist：IDCP）が 1 名, 専従薬剂師 (IDCP) が 1 名, 看 護師長, 主任を含む専従看護師 (Certified Nurse in Infection Control : CNIC) が 3 名, 専従事務員が 2 名の計 8 名で構成されている。 なお，2004 年 4 月から感染症対 策室業務の拡充目的で, 薬剤師が専従として活動してい る.

\section{感染制御活動における薬剤師の役割}

感染制御活動の具体的な内容は, 2014 年 12 月に発出 された厚生労働省医政局地域医療計画課長通知「医療機 関等における院内感染対策について」で明確にされてい $ろ^{5)}$. 感染制御活動では, 院内の感染事例をいち早く察 知し, 的確に感染対策の指導を行うことが重要である. また, 平時の活動は, サーベイランスに基づいた感染対 策の立案や教育・啓発, 抗菌薬の適正使用を行って院内 感染の発生を予防する。感染制御活動では各職種が専門 的な立場から関与しており, 薬剂師も担当すべき活動が 明記されている ${ }^{6)}$. ここでは, 当院感染制御部の活動を 示すとともに薬剤師の役割を以下にまとめた.

\section{1. 院内感染事例の把握と感染対策の指導}

ICT が把握する院内感染事例は, 感染症発生届や微 生物の検出状況, 医療関連感染サーベイランス, 抗微生 物薬の使用状況などから把握している. 薬剤師は抗菌薬 や抗ウイルス薬の使用から感染症の発生を推理し, 時間 的ずれや報告漏れが伴う感染症発生届とは別な角度から 院内感染事例の把握と分析を行う. 特定の病棟における 抗 MRSA 薬の使用患者の増加は, 関連する MRSAの 発生を疑うことが可能である。 また，抗インフルエンザ 薬の使用はインフルエンザの疑いやその発生を意味する.

薬剂師が行う感染対策の指導では, 感染対策の基本で ある手指消毒や環境表面からの微生物の伝播を抑制する
消毒薬の適正使用に関与することが望ましく，手指衛生 や医療環境における病原微生物の感染制御に関するガイ ドラインの利用は欠かせない ${ }^{7 \sim 11}$. 当院では私立大学病 院感染対策協議会（私大協）発行の「感染対策に携わる 薬剤師のための ICT ラウンドガイド」 ${ }^{12)} に$ 基づいて, 定 例の感染対策ラウンドを行っており, 病棟に保管されて いる感染リスクの高い吸入薬などの管理状況の把握や消 毒薬の適切な管理, 開封後の期限のチェックなどを担当 している.

\section{2. 院内感染の発生率に関するサーベイランス等の情} 報分析と評価に基づいた効率的な感染対策の立案

不適切な抗菌薬の使用は患者の予後のみならず耐性菌 の発生に大きく関わる。したがって, 病院全体の抗菌薬 の使用状況だけではなく, 診療科別の抗菌薬使用動向と 耐性菌の検出を関連付けて監視する. 抗 MRSA 薬のリ ネゾリドやカルバペネム系薬をはじめとする広域抗菌薬 は, その使用量に応じて感受性率が変化しやすい泣, 14). したがって, 厳密に監視し, 使用量とともに耐性菌アラー トシステムや抗菌薬適正使用マニュアルの作成を行う ${ }^{15}$. また, 手指消毒薬の使用量の把握に加えて, 手指衛生遵 守向上のためのキャンペーンなどの企画にも積極的に関 与する ${ }^{16)}$. 当院では, 薬剤師が参画し, 感染管理認定看 護師とともに看護管理者を対象とした手指衛生向上プロ グラムを推進した。本プログラムは看護部目標の成果尺 度として, 擦式アルコール手指消毒薬（Alcohol-Based Hand Rub：ABHR）の使用量を一般病棟とクリティカ ル部門でそれぞれ 15 および 30 (L/1,000patient-days) と設定し, 各看護師長に目標達成を義務付けた。また, 看護師長会議で毎月の ABHR 使用量と MRSA 検出数を 報告し, リンクナースと感染症対策室が目標達成の支援 を行った。 その結果, 一般病棟の ABHR 使用量 (L/1,000 patient-days) は, 導入前 2015 年の 9.3 から, 導入後 2017 
表 1 感染経路別ゾーニングシステムゾーンとインデックスカ ラーの設定

\begin{tabular}{|c|c|c|}
\hline Zone $A$ & $\begin{array}{l}\text { Aゾーン } \\
\text { (黄色) }\end{array}$ & $\begin{array}{l}\text { 空気予防策ゾーン } \\
(\text { 結核・麻疹・水痘 })\end{array}$ \\
\hline Zone B & $\begin{array}{l}\text { Bゾーン } \\
\text { (青色) }\end{array}$ & $\begin{array}{c}\text { 飛沫予防策ゾーン } \\
\text { （インフルエンザ・流行性耳下腺炎など） }\end{array}$ \\
\hline \multirow[t]{2}{*}{ zone C } & $\begin{array}{l}\text { Cゾーン } \\
\text { (緑色) }\end{array}$ & $\begin{array}{c}\text { 接触予防策ゾーン } \\
\text { （多剂耐性菌感染症・感染性胃腸炎など） }\end{array}$ \\
\hline & $\begin{array}{l}\text { Dゾーン } \\
\text { (白色) }\end{array}$ & $\begin{array}{c}\text { 標準予防策ゾーン } \\
\text { (外来・一般病室など） }\end{array}$ \\
\hline & 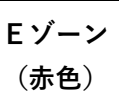 & $\begin{array}{c}\text { 污染管理物ゾーン } \\
\text { （感染性廃棄物保管場所） }\end{array}$ \\
\hline
\end{tabular}

年は 17.5 に倍増し $(\mathrm{P}<0.05)$, 目標を達成した。ささらに, 同時期の MRSA 発生率は 0.52 から 0.37 (件数 $/ 1,000$ patient-days) に減少した $(\mathrm{P}<0.05)$. クリティカル部 門でも同様の結果であった ${ }^{17)}$ (図 1). 現在も双方で目標 值は達成しており, 当院での手指衛生文化は根付いてい る.

\section{3. 職員に対する感染対策の教育}

手指消毒薬も含めた消毒薬や抗菌薬の適正使用に関す る教育を行う。薬剤師は手指消毒薬の効果や副作用（手 荒れやアレルギーなど), 使用感, 医療経済性にも言及 可能である. また, 患者周囲環境における清拭消毒薬の 選択や方法だけではなく自施設の課題を明らかにして, エビデンスに基づいた対策を盛り込むことが望ましい ${ }^{18)}$. 同様に, 抗菌薬の適正使用を教育的に推進する上では, 臨床的有用性や耐性菌の問題など，文献や各種ガイドラ インからの引用も効果的である。また，感染予防に関す る教育も重要で, 当院では職員に対する予防策の徹底を 目的に, 薬剤師も関与して新たな支援策「感染経路別ゾー ニングシステム」を導入した。 このシステムは, 米国疾 病管理予防センター (Center for Disease Control and Prevention：CDC）が提唱する感染経路別予防策を根 拠に ${ }^{19)}$ ，実施すべき予防策を指標色（color coding）に より視覚的に職員に周知させることを目的とした。すな わち, 空気予防策が必要な区域を A ゾーン (黄色), 飛 沫予防策区域は B ゾーン (青色), 接触予防策区域を C ゾーン (緑色), 標準予防策区域は Dゾーン (白色), 污染物管理区域を Eゾーン (赤色) とし, 各ゾーン内 で行う予防策の具体的手順を規定化した（表 1）（図 2). このシステムを導入した 2006 年度前後において, 接触 予防策として必須である医療用手袋は，261,700 枚/月か ら 410,100 枚/月へと 1.5 倍増加した. また, MRSA 感 染症および保菌患者の月別平均報告件数も $23.6 \pm 4.3$ か ら $19.8 \pm 4.6$ へと有意に減少した ${ }^{20)}(\mathrm{P}<0.05)$. このゾー

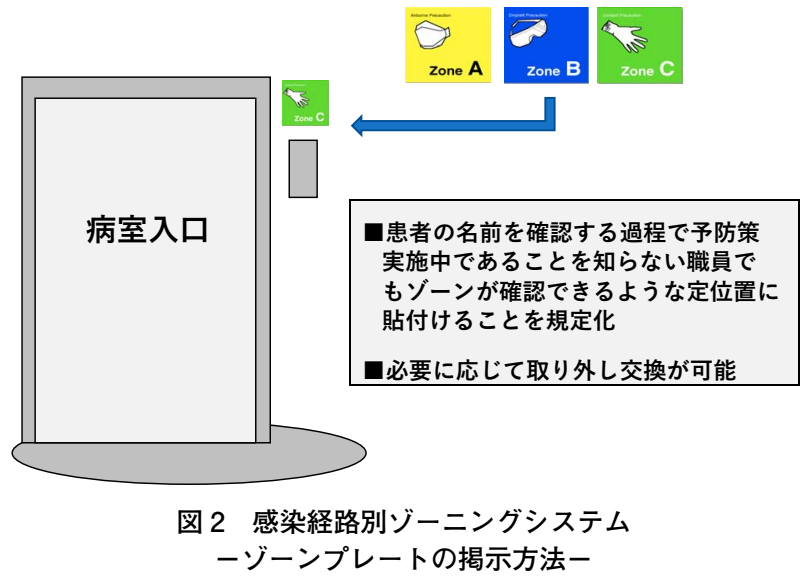

ニングシステムは, 現在もなお当院の感染対策の基本戦 略として継続的に実施している.

\section{4. 抗菌薬適正使用}

抗菌薬の適正使用は, 最大限の治療効果と副作用の軽 減や耐性菌の抑制を目的に行われる。 また, 抗菌薬適正 使用加算の取得は病院経営にも貢献することを念頭に置 く，薬剤師自身がAST の組織設立に関わることで，目 標や結果を意識し, 目に見える成果を出すことが可能と なる ${ }^{21)}$. 各診療科との調整や活動日 - 時間 ・活動内容の 決定など，簡単ではないが, 自らが企画・立案すること で抗菌薬の適正使用に大きく貢献できる. なお，加算の 要件となる抗菌薬適正使用への介入のための許可制や届 け出制の取り組みは, その領域から薬剤師が担当するこ とによって効果的に進めることができる，当院では，医 師と薬剂師を中心に, 注射用抗菌薬の独自のレベル分類 とレベルごとの理由書提出の義務化, 抗菌薬の処方履歴 カードの利用と払い出し処方日数の制限等を組み合わせ た「注射用抗菌薬の包括的処方管理システム」を導入し た. 導入後の 2004 年度には広域抗菌薬の使用量および 薬剂耐性菌の分離数は大きく減少し, 注射用抗菌薬の購 入額の削減を可能とした．注射用抗菌薬の総使用量 (antimicrobial use density: AUD) を月平均でみると, 導 入前の $377.3 \pm 62.1$ から, 導入後 5 年間はそれぞれ, 299.4

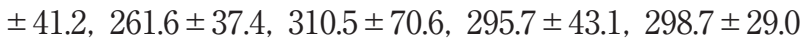
とそれぞれ有意に減少した $(\mathrm{P}<0.05)$. 特にカルバペネ ム系薬, キノロン系薬, 第 4 世代セフェム系薬などの広 域抗菌薬は導入前と比較して大きく減少した。 また, 緑 膿菌に対する耐性率は，イミペネム・シラスタチンおよ びメロペネムがシステム導入後に減少傾向を認め, 2003 年と 2008 年度の比較において，それぞれともに $24.7 \%$ から $7.7 \%$ と有意に減少した ${ }^{22)}(\mathrm{P}<0.05)$ (図 3). なお, 現在ではこの仕組みを利用した電子カルテ運用を継続し ている，単純な比較はできないが, 私大協の抗菌薬使用 


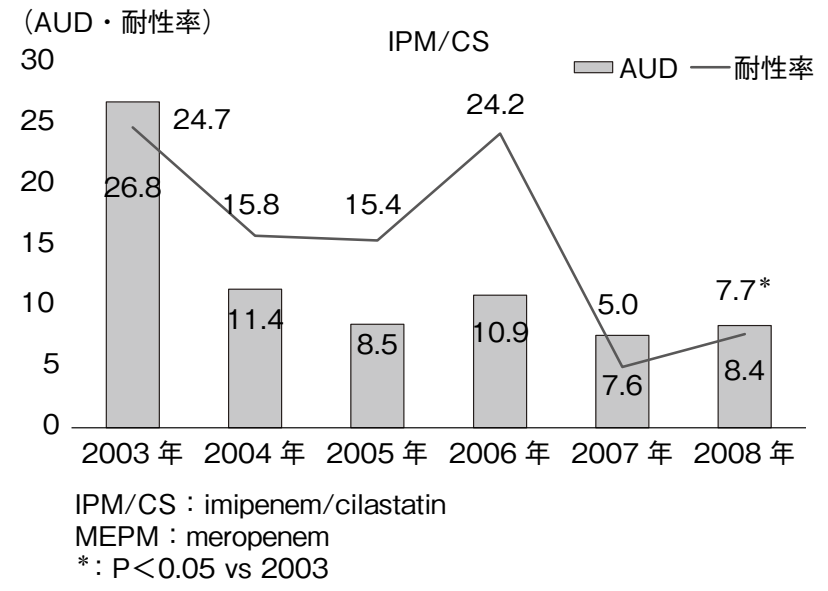

図 3 IPM/CS および MEPM の使用量

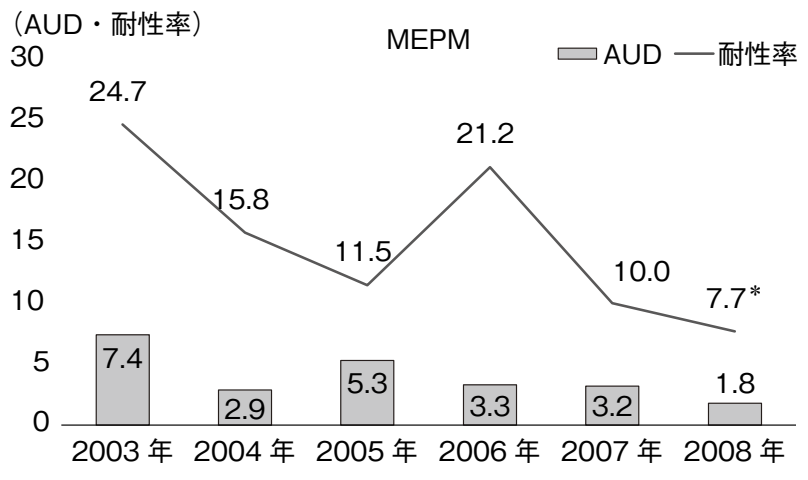

（AUD）と緑膿菌の耐性率の推移
量サーベイランスに準拠した 2019 年度の注射用抗菌薬 の使用量（AUD）は，1,000 患者入院のべ日数あたりの 換算で 166.2 となっている.

\section{感染制御に関わる認定・専門薬剤師の認定取得の必要性} 前述の通り，感染制御活動は多岐にわたっており，し かもその専門性が高い. チーム内での知識や技術を共有 するためには, 薬剤師も十分なトレーニングを受ける必 要がある. そのためには, 感染制御に関わる認定や専門 薬剤師の取得が望ましい. 日本病院薬剤師会では 2004 年に感染制御専門薬剂師制度を, 日本化学療法学会は 2008 年に「抗菌化学療法認定薬剂師」制度を創設した。 その認定条件は, 一定単位の研修が義務化され, 感染制 御活動実績や感染症治療に関わった症例, 認定試験など が課せられている ${ }^{23,24)}$.

日本病院薬剂師会は, 感染制御専門薬剂師の理念につ いて, 「感染制御専門薬剤師は, 感染制御に関する高度 な知識, 技術, 実践能力により, 感染制御を通して患者 が安心・安全で適切な治療を受けるために必要な環境の 提供に貢献するとともに, 感染症治療に関わる薬物療法 の適切かつ安全な遂行に寄与することを目的とする」と している ${ }^{23)}$. すなわち, 抗菌薬の適正使用のみならず消 毒薬や医薬品に関わる感染制御活動など, 総合的な観点 から関与すべきであると謳っている。一方で, 日本化学 療法学会では, 抗菌化学療法認定薬剤師について, 「TDM のデータをもとに抗菌薬の投与設計を医師に助言する役 割から脱却し, 感染症の種類や病態に応じた抗菌薬の選 択，その使用方法, 評価まで担う存在である」と言及し ている ${ }^{24)}$

\section{感染制御活動における薬剤師の立ち位置と心構え}

感染制御活動において薬剤師が力を発揮するためには, 感染制御部門である ICT および AST での相互的な関与
が望まれる，すなわち，感染制御と感染症治療支援の双 方を薬学的な視点から関与できることが薬剤師の職能で あり，科学的根拠に基づいて，目に見える形での成果を 上げることが重要である。薬剤師は, 歴史的に薬局内で の業務(調剤や製剂, 医薬品情報の提供など)が中心だっ た経緯があり，服薬指導業務や病棟業務，チーム医療へ の参画歴は長くはない. したがって, 多職種との関わり は情報の収集や分析，提供などが主であった。今後は, 薬剤師ならではの “情報収集・分析”の偏重から“企画・ 立案”にチャレンジし, 自ら責任を負う覚悟も必要であ る. そこには情報収集・分析能力はもちろんのこと, 企 画力や指導力, コミュニケーション能力が必要なことは 言うまでもない.

\section{ICT あるいは AST 活動で当院の薬剤師が企画・立案に 関わった最近の活動例}

1. 耐性菌多発時の多面的関与 (疫学解析・手指衛 生・環境整備・教育など）

2018 年 6 月～ 2019 年 1 月，新生児集中治療管理室 (NICU) において MRSA が継続的に検出された. ICT を中心に強化対策を行うなか, 2019 年 6 月に薬剤師も MRSAの発生要因の分析と「スタッフ全員参加 M ゼロ キャンペーン」を企画した。 チャレンジ項目として, (1) 手指衛生（多職種を対象としたポシェットの推進・エリ ア別の目標值の設定), (2)環境整備（定時に環境消毒を 一斉に行うクリーンタイムの設定)，(3患児の移動制限 (MRSA 拡散防止を目的とした重症度によるベッド移動 の制限)，(4)教育・啓発（チームステップスの推進）の 4 つを設定し，全員参加で 2 ヶ月間実施した。 その結果, キャンペーン遵守率は $93.5 \%$ で, 継続的発生時期とキャ ンペーン後における MRSA の発生数/月は, $2.3 \pm 0.7$ か ら $1.0 \pm 0.7$ に減少した $(\mathrm{P}<0.05)$ （図 4). その後 2020 年 9 月に新病院に移転したが, 現在も MRSA の発生は 


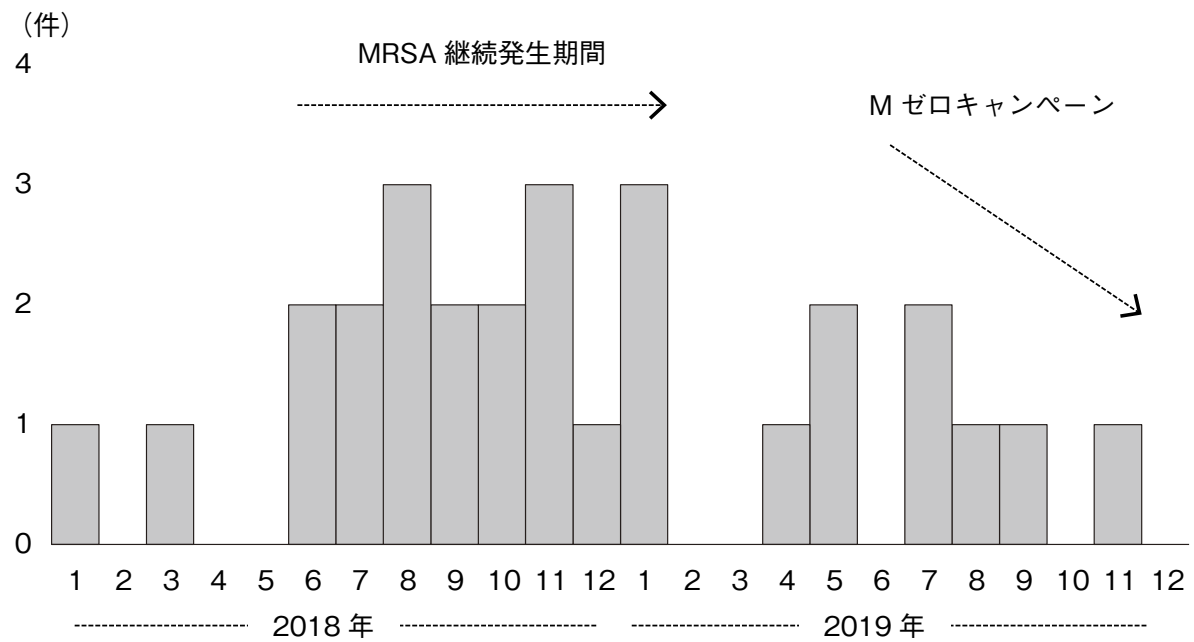

図 4 NICU における MRSA 発生状況

コンサルテーション依頼

AST専従薬剂師 (IDCP)
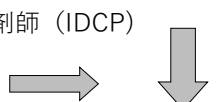

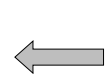

病棟薬剂師

i

総合診療科 呼吸器内科 救急科 消化器内科 消化器外科

感染制御部 副部長/薬剤師

$(\mathrm{ICPS} \cdot \mathrm{IDCP})$

\section{図 5 コンサルテーションシステム}

(1)感染制御部薬剂師がコンサルテーションに関する内容について, 主治医, 病棟薬剤師やリンクナース, 臨床検査技師から情報を収集 し, 取りまとめる. (2)薬学的視点から抗菌薬等の選択・用法用量 · 投与期間などを検討し, AST 医師と相談して返答する. 対応困難 な症例は, 副部長の薬殽師が顧問契約している感染症医に相談す る.

コントロールされている.

2. AST加算取得に向けた Antimicrobial Stewardship の推進

当院では感染症専門医が在籍していないため薬剤師が 中心となって, AST 加算取得に向けた取り組みを行っ た．AST 組織の設立や構成メンバーの選定，コンサル テーションシステムの構築を行い, 参加メンバーは多職 種で構成され 20 名を超えている (図 5). AST 活動で は各診療科との関係性と教育的効果を重視し, 診療科担 当者や研修医の症例検討会への参加を義務付け, 抗菌薬 使用例を紹介することになっている。 2020 年 4 月〜 9 月 の症例検討㧍よびラウンド数は 117 件であった（救急科 や外科症例をはじめ 20 診療科に関与). AST 設立前の 感染症治療に関するコンサルテーションは数件程度で あったが，76件と大きく増加した．なお，ASTがフィー
ドバックした抗菌薬等の選択やデ・エスカレーションの 検討依頼, 投与設計に関する助言などに対する診療科の 採択率は 47/56 件 (83.9\%) であった。

\section{おわりに}

感染制御活動は, 院内感染事例の把握や感染対策の指 導, サーベイランスに基づいた感染対策の立案, 教育・ 啓発，抗菌薬適正使用などとされているが，そのなかで も薬剤師が積極的に関与すべき活動は少なくない，現在 では, 薬剤師も専門的スキルを学ぶために日本病院薬剤 師会や日本化学療法学会での認定や専門薬剤師制度も整 備されている。このような背景のもと, 感染制御活動に おいて薬剂師が力を発揮するためには, 専門的知識や技 術の習得と感染制御活動における薬剤師の立ち位置や心 構えも重要となる. 薬学的視点から感染制御の総合的な 関わりを求めた感染制御専門薬剤師の理念に基づいて, 感染制御部門である ICT および AST での相互的な活動 を意識し, 目に見える形の成果が必要となる。そして, 薬学の知識を基本とした科学的エビデンスにこだわった 感染対策の立案, 効率的な運用と的確な評価を行って, 成果に導くことがその実現に向けた近道になると考える。

この内容は一部, 第 35 回日本環境感染学会総会「Meet the Expert」にて発表した.

利益相反自己申告：申告すべきものなし．

文献

1）吉倉 廣, 荒川宜親：小林寬伊編, エビデンスに基づいた 感染制御. 第 1 集 基礎編, 改訂 2 版, メヂカルフレンド社, 東京, 2003.

2）小林寬伊：医療関連感染制御の変遷．薬剤師のための感染 制御マニュアル第 4 版，薬事日報社，2017. p. 3-15. 
3）国公立大学附属病院感染対策協議会：病院感染対策ガイド ライン 2018 年版：病院感染対策の組織づくり，医療法，地 域連携, 2018. p. 214-21.

4）前田真之：抗菌薬適正使用支援チームが効果的に活動する ためのストラテジー. 日本化学療法学会雑誌 2020; 68(2): 204-9.

5）厚生労働省：医療機関等における院内感染対策について： 厚生労働省医政局地域医療計画課長通知/医政地発 1219 第 1 号 2014 年.

6）木津純子：感染制御における薬剂師の役割. エビデンスに 基づいた感染制御，メヂカルフレンド社，2003. p. 89-96.

7) WHO Guidelines on Hand Hygiene in Health Care: http:// whqlibdoc.who.int/publications/2009/9789241597906_eng.p df. accessed October 1, 2020.

8) SHEA/IDSA: Strategies to Prevent Healthcare-Associated Infections through Hand Hygiene: http://www.jstor.org/st able/full/10.1086/677145. accessed October 1, 2020.

9) CDC: Guidelines for Environmental Infection Control in Health-Care Facilities. MMWR 2003 ; 52(RR-10): http://ww w.cdc.gov/mmwr/PDF/rr/rr5210.pdf. accessed October 1, 2020.

10) CDC: Management of Multidrug-Resistant Organisms in Healthcare Settings, 2006: http://www.cdc.gov/ncidod/dh qp/pdf/ar/mdroGuideline2006.pdf. accessed October 1, 2020.

11) CDC: Guideline for Disinfection and Sterilization in Healthcare Facilities 2008: http://www.cdc.gov/hicpac/pdf/guide lines/Disinfection_Nov_2008.pdf. accessed October 1, 2020.

12）私立医科大学病院感染対策協議会薬剂師部会：感染対策に 携わる ICT ラウンドガイド第 2 版. 2017 : https://www.id aikyo.or.jp/kansen.html : 2020 年 10 月 1 日現在.

13）水野秀一：新たに分離されたリネゾリド耐性 MRSA 株の分 子遺伝学的解析. 山口医学 2011; 60(6): 223-30.

14）具 芳明, 大曲貴夫：海外に扔ける薬剂耐性と抗菌薬使用 の現状. 日本化学療法学会雑誌 2018; 67(1): 13-22.

15) Bethany AW, John AS, Kari AM: Outpatient antimicrobial stewardship: Optimizing patient care via pharmacist led microbiology review. Am J Infect Control 2020; 48(2): 18993.

16) SHEA/IDSA: Strategies to Prevent Healthcare-Associated Infections through Hand Hygiene: http://www.jstor.org/st able/full/10.1086/677145. accessed October 1, 2020.

17）嶋守一恵, 近藤啓子, 小野寺直人, 佐藤悦子, 櫻井 滋 : 看護管理者を対象とした手指衛生向上プログラムの検証： 手指消毒薬使用量および耐性菌検出に与える影響. 看護管 理学会. 日本環境感染誌 2017; 32(5): 268-74.

18）小野寺直人：病院清掃のための拭き掃除「感染対策におけ る拭き消毒」の科学的根拠. 感染対策 ICT ジャーナル. ヴァ ンメディカル 2020; 15(1): 5-11.

19) CDC: 2007 Guideline for Isolation Precautions: Preventing Transmission of Infectious Agents in Healthcare Settings: http://www.cdc.gov/hicpac/pdf/isolation/Isolation2007.pd f. accessed October 1, 2020.

20）小野寺直人, 櫻井 滋, 吉田 優, 小林誠一郎, 高橋勝雄 : 大学附属病院における新たな感染制御支援策「感染経路別 ゾーニング・システム」導入の経緯と効果. 日本環境感染 誌 2008; 23(1): 58-65.

21) Zhongwang Li, Baoli C, Kai Z, Guohao X, Yan W, Jinchao $\mathrm{H}$, et al:: Pharmacist-driven antimicrobial stewardship in intensive care units in East China: A multicenter prospective cohort study. Am J Infect Control 2017; 45(9): 983-9.

22）小野寺直人, 櫻井 滋, 高橋美枝子, 山田友紀, 諏訪部章, 佐藤 譲, 他：注射用抗菌薬の包括的処方管理システムの 有用性. 日本化学療法学会雑誌 2011; 59(3): 285-92.

23）日本病院薬棛師会：感染制御専門薬棛師の理念と目的：htt $\mathrm{p}: / /$ www.jshp.or.jp/senmon/senmon2.html : 2020 年 10 月 1 日現在.

24）日本化学療法学会：抗菌化学療法認定薬剤師制度につい $\tau$ : http://www.chemotherapy.or.jp/qualification/pharma cist_about.html : 2020 年 10 月 1 日現在.

〔連絡先： $\bar{\top} 028-3695$ 岩手県紫波郡矢巾町医大通二丁目 1-1 岩手医科大学附属病院感染制御部 小野寺直人 E-mail: naoto.onodera@j.iwate-med.ac.jp] 
What Should Pharmacists Do to Contribute Their Expertise to Infection Control Activities?

\author{
Naoto ONODERA
}

Department of Infection Control and Prevention, Iwate Medical University Hospital

\begin{abstract}
With the aim of preventing infectious disease occurrence and spread among patients and staff in hospitals, infection control greatly contributes to medical safety and the improvement of quality of care. Pharmacists play important roles in multidisciplinary initiatives regarding infection control. Pharmacists have been actively involved in infection control at Iwate Medical University Hospital, since a full-time pharmacist was assigned to the Infectious Disease Control Office in April 2004. They have been involved in initiatives such as the transmission-based zoning system, the comprehensive prescription management system for antibacterial agent use, and handwashing campaigns. In addition, the mission of board-certified infection control pharmacy specialists is to address the importance of taking comprehensive measures, including the proper use of antimicrobial drugs, disinfectants, and medical supplies. To leverage their expertise in infection control activities, pharmacists need to understand the reciprocal relationship between the infection control team and antimicrobial stewardship team and produce tangible outcomes. In this respect, pharmacists should shift their overemphasis from "information gathering and analysis" and to developing "plans." To do so, they should observe infection control from a wider perspective and should propose plans based on scientific and pharmaceutical evidence and operate the activities efficiently, with proper evaluation, for successful results.
\end{abstract}

Key words: infection control, infection control team, antimicrobial stewardship team, boardcertified infection control pharmacy specialist 